terminations will be carried out at the Atomic Energy Commission's laboratories at Risø. An integration of the log-curves will also be prepared. These results, together with the geological observations, will form the basis for new calculations of the $\mathrm{U}$ tonnage on Kvanefjeld.

\title{
References
}

Sørensen. H. 1969 : Field work in the Ilimaussaq intrusion. Rapp. Gronlands geol. Unders. 19, $37-38$.

Sørensen, H., Hansen, J. \& Bondesen, E. 1969: Preliminary account of the geology of the Kvanefjeld area of the Ilímaussaq intrusion, South Greenland. Rapp. Gronlands geol. Unders. 18.

Sørensen, H., Hansen, J. \& Nielsen, B. Leth 1969: Rapport over undersøgelser af uranforekomsterne på Kvanefjeldsplateauet 1964-1968 med et forslag til et nyt boreprogram. Internal GGU report.

\section{, \\ THE INTERNATIONAL HYDROLOGICAL DECADE PROGRAMME IN NARSSAQ RIVER VALLEY, SOUTH GREENLAND}

\section{Leo Larsen}

The Hydrological Decade Programme in Narssaq river valley started in 1965. In 1966 and 1967 work was concentrated on establishment of decade stations in order to collect data concerning precipitation, runoff, evapotranspiration and reservoirs. Collection of these basic data is of major importance for the calculation of the water balance and at the end of the summer 1969 these parameters were being investigated as follows:

Mean precipitation is to be calculated from 6 precipitation gauges placed in the $33 \mathrm{~km}^{2}$ area according to the topography.

It is most important in runoff studies to establish the stage-discharge relations. Determination of stage is being made by five water stage recorders of which three are placed at points along the Narssaq river and two in the tributaries. The main hydrometric station measuring the total runoff is placed in the Narssaq river close to the sea.

Field measurement of evapotraspiration is very difficult and instead of this, a theoretical approach based on the physics of the evapotranspiration process is used. To collect the data needed, four weather stations have been placed in the area measuring maximum, minimum and actual temperature, relative air humidity, atmospheric pressure, velocity and direction of the wind.

The reservoirs are Narssaq glacier, Taseq lake and groundwater.

Detailed studies of Narssaq glacier were started in 1967 and have not been finished 
yet. The study includes classification, mass budget, glacier runoff and glacier flow.

Possible future extraction of the uranium-thorium ores at Kvanefjeld by flotation will demand a definite quantity and quality of water. These demands can easily be met in the frost-free period of the year but may be a problem in the winter time. Therefore a special water balance has been made for Taseq lake which showed that the lake, with a volume of $1.87 \times 10^{7} \mathrm{~m}^{3}$, is big enough to supply the industry during the winter. This work is finished and will be reported at the end of 1969 or the beginning of 1970 together with a report covering all work from the first part of the decade.

During the summer this year the groundwater in the sediments of Narssaq river valley was mapped.

Because the occurrence of groundwater is limited to permeable geologic formations the main part of the Narssaq river area is of no interest in groundwater studies. The rocks of the area are for the most part impermeable but in the bottom of the Narssaq river valley there is a system of Quaternary deposits which serve as reservoirs for groundwater. On both the northern and the southern side of Narssaq river the alluvial deposits make up a system of terraces consisting of three generations, excluding the present river bed which makes up the lowest level in the system. The terraces range from sea level in the west to an altitude of $100 \mathrm{~m}$ in the east, where the tributaries Kvane river and Taseq river limit the area. To the north and south the steep walls of Narssaq Fjeld and Qáqárssuaq respectively form a natural limit to the groundwater system which covers an area of about $3 \mathrm{~km}^{2}$.

The grain size of the material ranges between silt and boulders with the main part in the sand-gravel fractions. The terrace system forms a typical unconfined aquifer in which the water table serves as the upper surface of the zone of saturation.

From field measurements of water levels in five dug wells and several springs, a water table contour map has been constructed. Because of the relatively small differences in groundwater level from point to point all these measurements have been made with theodolite. This hydrogeological mapping was one of the two main fields of investigation this summer. The other was a study of the variations of the groundwater table. The fluctuations of the groundwater level were measured in three of the five dug wells mentioned above. For three months the levels were recorded every day and the fluctuations showed a close correlation with the variations in rainfall. Besides the seasonal fluctuations, alternating series of wet and dry years in which the rainfall is above or below the mean will produce long-period fluctuations, called secular variations. In order to detect all these variations a water stage recorder was placed in a $4.2 \mathrm{~m}$ deep well and by June 1970 variations will have been measured for one year.

The work this summer also comprised field measurements of permeabilities by pumping tests and by tracers. To get an exact value of the porosity some samples of the sediments are being examined in the laboratory.

All over the Narssaq river area measurements of temperature and conductivity of the water are being made and samples collected for chemical analysis. The groundwater is now also the subject of these measurements. 